\title{
THE IMPORTANCE OF SOIL CONDITIONERS CONTROLLING BACTERIAL BIODIVERSITY OF VEGETABLE FIELDS UNDER CONTINUOUS CROPPING
}

\author{
ZHANG, D. ${ }^{*}-$ JIANG, B. W. - LV, S. \\ Department of Resources and Environmental Science, Northeast Agricultural University \\ Harbin, Heilongjiang 150030, China \\ *Corresponding author \\ e-mail: zhangdi6283@neau.edu.cn \\ (Received 17 th $^{\text {th }}$ Dec 2018; accepted 20 $0^{\text {th }}$ Feb 2019)
}

\begin{abstract}
A soil-borne fungal parasite (Plasmodiophora brassicae Woron) has regularly caused 50-60\% reductions in the seasonal yield of a 35 years old cabbage plantation under garlic revaccination in China. We investigated the impact of soil conditioners on soil chemical properties and bacterial communities in order to recommend actions to address increasing frequencies of root-resistant cabbage infections. The results showed urease and polyphenol oxidase activities increased by $10.4-15.8 \%$ in the topsoil after two-years of quicklime and organic fertilizer application. High throughput sequencing data showed significant increases in the relative abundance of bacteria with potential for biocontrol (Xanthomonadales, Pseudomonas, and Bacillus) under lime and bioorganic fertilizer. Also, according to a forward-selection CANOCO analysis, in this case the two most important variables contributing to the variation in bacterial communities' composition were soil organic matter and total nitrogen.
\end{abstract}

Keywords: soil-borne parasites, antibiotic bacteria, high throughput sequencing, lime, soil enzyme activities

\section{Introduction}

Agricultural cropping systems are intensive and involve crop rotations among a limited number of species under specific climatic conditions in China (Chen et al., 2015). Extensive intensification of cropping has been achieved through high inputs of chemical fertilizers, which, in turn, seriously degraded soil physicochemistry and reduced the diversity and abundance of soil bacteria communities (Xiong et al., 2015). Continuous cropping can decrease soil $\mathrm{pH}$ from neutral to acidic levels (Wang et al., 2014), and can increase root exudates, such as amino acids, phenolic acids, root cap cells, cellular debris, etc. (Wei et al., 2015b). These changes to agricultural soils and their bacterial communities increase the vulnerability of crops to pests and diseases (Yin et al., 2010). Consequently soil-borne parasites become particularly difficult to control with alternative pesticide techniques due to the long-term survival of resistant spores and eggs in the soil (Fukuta et al., 2013). Manipulation of soil conditioners is one potential approach to address soil-borne parasites. As the capacity to process soil nutrients varies among groups of microorganisms, soil fertilization and acidity manipulation can influence growth and competitiveness of microorganism in different ways, and therefore affect the diversity, biomass, and activity of the soil microbial community. Chagnon and Bradley (2013) provide evidence that the relative availability of soil nitrogen $(\mathrm{N})$ and phosphorus (P; i.e., soil nutrient stoichiometry) controls the competitive balance between these two fungal guilds. Species richness and functional group richness affected community stoichiometry, especially by increasing C:P and N:P ratios. Compost application to agricultural fields is an excellent natural approach to 
fighting plant pathogens. Lime products have been used to destroy Salmonella or other pathogens present in soil and manure, and do not require any specialized equipment to apply, so lime can be recommended for temporal use, e.g., for rapidly destroying Salmonella or other pathogens. Lime amendments can be beneficial to acidic soils, which, in any case, require regular lime amendments (Dowling et al., 2015). Quicklime application can improved the effects of mechanical soil aeration, which can restrain pathogenic microorganism growth by reducing soil moisture and enhancing soil permeability (Wei et al., 2015a).

Microorganisms respond quickly to modifications in the vegetation or soil properties. Understanding the relationships between soil conditioners and microbial community structure and composition may significantly contribute to our knowledge regarding the development of better fertilizer regimes for extensive vegetable cropping systems (Glaser et al., 2015). When compared with traditional techniques for determination of the biological diversity, such as Polymerase Chain Reaction-Denaturing Gradient Gel Electrophoresis (PCR-DGGE), fluorescence in situ hybridization (FISH), and terminal restriction fragment length poly-morphisms (T-RFLP), high-throughput sequencing technologies can significantly expand investigations into species and functional diversity of microbial populations (Diaz et al., 2012).

As stated above, it appears that both soil acidity and nutrient levels can be manipulated to control fungal pathogens and improve the bacterial diversity and biomass in agricultural fields. In the agricultural site studied here, a soil-borne fungal parasite (Plasmodiophora brassicae Woron) often causes 50-60\% seasonal yield losses for the autumn cabbage crop in 35-year revaccination. We tested the hypothesis that: Soil conditioners effective in controlling pathogens may favor the development of bacteria with potential for biocontrol. We assessed the potential of these alternative control methods in soil-borne parasites and looked for significant insights into species and functional diversity of microbial populations.

\section{Materials and methods}

\section{Experimental site and crop management}

This experiment was carried out on a field site located in Baicheng County of Acheng City in Heilongjiang Province, China $\left(45^{\circ} 32^{\prime} \mathrm{N}, 126^{\circ} 58^{\prime} \mathrm{E}\right.$ and altitude $\left.151 \mathrm{~m}\right)$. The site soil is classified as fine Mollisols Albolls Argialbolls Argiaquic. The experimental site is located within a temperate continental monsoon climate with mean annual precipitation of $600 \mathrm{~mm}$ and mean temperature of $4{ }^{\circ} \mathrm{C}$. For at least 35 years before the experiment (see Table 1), the field site crop rotation had involved early garlic (Allium sativum L, April to July), late Chinese cabbage (Brassica campestris L. spp, July to October) and winter fallow (October to April). Continuous cropping changed the soil physicochemical properties and microbial community structure and has resulted in the establishment of a fungal pathogen.

\section{Field experiment design}

This two-year experimental manipulation of soil conditioners controlling (lime, Effective Microorganisms EM, bio-organic fertilizer) soil remediation under a continuous cropping system started in 2014, and involved six soil treatments. The six treatments were located on adjacent plots and included: (1) untilled soil (NTS) within an 
undeveloped field, means healthy soil; (2) continuously tilled soil (CTS) within a field with continuous crop production growing garlic and cabbage with raw chicken manure application (Table 1); In order to discuss the effects of soil conditioners on soil restoration under a 35 years old cabbage plantation under garlic revaccination. (3)-(6) treatments were set. It is forbidden to use raw chicken manure during the whole growth period. Chemical fertilizers are normally applied in accordance with conventional planting practices. (3) organic fertilizer treatment (OFT), based on a field with continuous crop production growing garlic and cabbage with base fertilizer and 1500 $\mathrm{kg} / \mathrm{ha}$ bio-organic fertilizer application; (4) quicklime and organic fertilizer treatment (LOF), within a field with continuous crop production growing garlic and cabbage with $4000 \mathrm{~kg} / \mathrm{ha}$ quicklime and $1500 \mathrm{~kg} / \mathrm{ha}$ bio-organic fertilizer application; (5) quicklime treatment (LIM), within a field with continuous crop production growing garlic and cabbage with $4000 \mathrm{~kg} / \mathrm{ha}$ quicklime (equivalent to $\mathrm{CaO} 2026 \mathrm{~kg} / \mathrm{ha}$ ) application; (6) $\mathrm{EM}$ treatment (EMT) within a field with continuous crop production growing garlic and cabbage with $5000 \mathrm{ml} / \mathrm{ha}$ EMT diluted 100 times and sprayed onto the soil after garlic and Chinese cabbage harvest. The EMT treatment also involved a supplemental application at the bulbil differentiation stage of garlic and the rosette stage of Chinese cabbage. Bio-organic fertilizer (decomposed biological organic fertilizer with microbial fungicide) included moisture content $30.0 \%$, organic matter $25.5 \%, \mathrm{~N} \% 2.69 \%, \mathrm{P}_{2} \mathrm{O}_{5} \%$ $0.96 \%, \mathrm{~K}_{2} \mathrm{O} 0.49 \%$, bacillus bacillus and bacillus granulus $\geq 0.2$ billions/gram. Besides the untilled soil treatment, others treatments applied the same concentration chemical fertilizer $\left(667 \mathrm{~m}^{2}\right.$ Garlic, $\mathrm{N} 15 \mathrm{~kg}, \mathrm{P}_{2} \mathrm{O}_{5} 20 \mathrm{~kg}, \mathrm{~K}_{2} \mathrm{O} 15 \mathrm{~kg}$; $667 \mathrm{~m}^{2}$ Chinese cabbage, $\mathrm{N}$ $15 \mathrm{~kg}, \mathrm{P}_{2} \mathrm{O}_{5} 7 \mathrm{~kg}, \mathrm{~K}_{2} \mathrm{O} 12 \mathrm{~kg}$;). The experiment was laid out as a randomized design of the six treatments with three replicates. Each plot was $60 \mathrm{~m}^{2}$ in area and surrounded by a $30 \mathrm{~cm}$ buffer to prevent the water and nutrient exchange between adjacent plots.

Table 1. Cropping model and manure input before experimental field

\begin{tabular}{|c|c|c|}
\hline Schedule & Cropping method and manure input & Planting method and density \\
\hline Late April & $\begin{array}{l}\text { Grown early garlic, The proper } 42 \% \text { compound fertilizer } \\
\left(\mathrm{N}_{-} \mathrm{P}_{2} \mathrm{O}_{5}-\mathrm{K}_{2} \mathrm{O}=20: 8: 14\right) \text { application and dressing ratios for } \\
\text { garlic(Allium Sativum L.) were } 600 \mathrm{~kg} / \text { ha and } 2: 1 .\end{array}$ & $\begin{array}{c}\text { Chinese cabbage was planting by plot, } \\
\text { with the width of } 2.2 \text { meter x length } \\
100 \text { meter. It is generally advisable to } \\
\text { plant } 3,800 \text { plants } / 667 \mathrm{~m}^{2} .\end{array}$ \\
\hline Early July & Harvested early garlic & \\
\hline Middle July & Applied $37500 \mathrm{~kg} / \mathrm{ha}$ raw chicken manure & $\begin{array}{l}\text { Garlic Seeding density using } \\
\text { traditional narrow ridge system }\end{array}$ \\
\hline Late July & $\begin{array}{c}\text { Grown late Chinese cabbage, Fertilizer applied N } 124 \\
\mathrm{~kg} / \mathrm{ha}, \mathrm{P}_{2} \mathrm{O}_{5} 90 \mathrm{~kg} / \mathrm{ha}, \mathrm{K}_{2} \mathrm{O} 150 \mathrm{~kg} / \mathrm{ha} \text {. Chemical fertilizers } \\
\text { are } 46 \% \text { urea, } 46 \% \text { triple-superphodate, } 50 \% \text { potassium } \\
\text { sulfate }\end{array}$ & $\begin{array}{c}45 \mathrm{~cm} \times 6 \mathrm{~cm}, \\
24,700 \text { plants } / 667 \mathrm{~m}^{2}\end{array}$ \\
\hline Early October & Harvested late Chinese cabbage & \\
\hline Middle October & $\begin{array}{c}\text { Applied } 46875 \mathrm{~kg} / \mathrm{ha} \text { raw chicken manure and winter } \\
\text { fallow until next April }\end{array}$ & \\
\hline
\end{tabular}

The nutrient content of raw chicken manure: Moisture content 50.5\%; Organic matter 25.5\%; N\% $1.63 \% ; \mathrm{P}_{2} \mathrm{O}_{5} \% 1.54 \% ; \mathrm{K}_{2} \mathrm{O} 0.85 \%$

\section{Soil sampling}

Soil samples were collected in October 2015 after the Chinese cabbage harvest. Soil samples, up to a depth of $0.60 \mathrm{~m}$, were collected using an $85 \mathrm{~mm}$ diameter soil corer and divided into three depth layers $(0-0.20,0.20-0.40$, and $0.40-0.60 \mathrm{~m})$. For each treatment, three replicate samples were collected according to a completely randomized 
design. Each replicate was composed of three subsamples, which were mixed and transported to the laboratory on the same day. Soil samples for microbiological analysis were subsequently wet sieved $\left(4 \mathrm{~mm}\right.$ mesh sieve) and stored at $-80^{\circ} \mathrm{C}$.

\section{Soil chemical properties and microbial biomass}

The air-dried soil sieved by $(0.25 \mathrm{~mm})$ was analyzed for organic $\mathrm{C}$ by vitriol acid potassium dichromate oxidation method (SOC), total $\mathrm{N}$ by the Kjeldahl method (TN) and total $\mathrm{P}$ by the $\mathrm{HClO}_{4}-\mathrm{H}_{2} \mathrm{SO}_{4}$ method (TP), and soil $\mathrm{pH}$ was measured in a $1: 2.5$ (soil:water) mixture using the potentiometric method. Other parameters and specific analysis methods were determined as described by Forster (1995). Microbial biomass C $\left(\mathrm{C}_{\text {mic }}\right)$ and biomass $\mathrm{N}\left(\mathrm{N}_{\text {mic }}\right)$ contents were determined on the $4{ }^{\circ} \mathrm{C}$ component using the chloroform-fumigation-extraction method (Vance et al., 1987). Extracts were filtered through Whatman no.42 filter paper and analyzed for organic $\mathrm{C}$ content with an elemental analyzer (TOC-VCPH/CPN, Shimadzu, Kyoto, Japan).

\section{Soil Enzyme activity measurements}

In order to investigate changes to soil biological functions, activities of key enzymes were determined immediately after air-drying soil $(<1 \mathrm{~mm})$. Soil urease (EC 3.5.1.5) activity (URE) was measured by incubating $5 \mathrm{~g}$ of soil in $0.5 \mathrm{M}$ urea as substrate in $0.1 \mathrm{M}$ phosphate buffer at $\mathrm{pH} 7.1$ under $37^{\circ} \mathrm{C}$ for $2 \mathrm{~h}$. The formation of ammonium was determined spectrophotometrically at $578 \mathrm{~nm}$ and URE activity was expressed as $\mu \mathrm{g}$ $\mathrm{NH}_{4}-\mathrm{N} \mathrm{g}^{-1}$ soil $^{-1}$ (Nannipieri et al., 1974). Soil sucrase (EC 3.2.1.26) activity (SUC) was measured by incubating $3 \mathrm{~g}$ soil (d. w.) according to Kandeler et al. (1999). The activity of SUC was expressed as $\mathrm{mg}$ glucose $\mathrm{g}^{-1}$ soil $^{-1}$ (Kandeler et al., 1999). Soil catalase (EC 1.11.1.6) (CAT) was measured by incubating $5 \mathrm{~g}$ soil in $5 \mathrm{ml}$ of a $0.3 \%$ $\mathrm{H}_{2} \mathrm{O}_{2}$ solution for $30 \mathrm{~min}$ at $30^{\circ} \mathrm{C}$. The suspension was titrated with a $0.1 \mathrm{~mol} \mathrm{~L}^{-1}$ $\mathrm{KMnO}_{4}$ solution. The activity of CAT was expressed as $0.1 \mathrm{~mol} \mathrm{~L}^{-1} \mathrm{KMnO}_{4} \mathrm{ml} \mathrm{g}^{-1}$ soil $30 \mathrm{~min}^{-1}$ (Author, 1964). Polyphenol oxidase (EC 1.10.3.1) activity (PPO) was determined as described by Peruccia (2000), and expressed as mg purpurogallin $\mathrm{g}^{-1}$ soil $2 \mathrm{~h}^{-1}$. Determinations for all soil samples were performed in triplicate, and all values were reported as averages of the three determinations. All rates were standardized to oven-dried soil mass.

\section{Soil DNA extraction and PCR amplification}

Microbial DNA was extracted from soil samples using the E.Z.N.A. ${ }^{\circledR}$ soil DNA Kit (Omega Bio-tek, Norcross, GA, U.S.) according to the manufacturer' s suggested protocols. For each sample three-four subsamples were independently taken and went through the extraction. Then the extracts from one sample were pooled together and the extracted DNA was stored at $-20^{\circ} \mathrm{C}$ until the subsequent sequencing procedure. The V4V5 region of the bacteria $16 \mathrm{~S}$ ribosomal RNA gene was amplified by PCR $\left(95^{\circ} \mathrm{C}\right.$ for $3 \mathrm{~min}$, followed by 27 cycles of $95^{\circ} \mathrm{C}$ for $30 \mathrm{~s}, 55^{\circ} \mathrm{C}$ for $30 \mathrm{~s}$, and $72^{\circ} \mathrm{C}$ for $45 \mathrm{~s}$, and a final extension at $72^{\circ} \mathrm{C}$ for $\left.10 \mathrm{~min}\right)$ using primers $\left(515 \mathrm{~F} 5^{\prime}\right.$ 'barcodeGTGCCAGCMGCCGCGG)-3' and 907R 5'-CCGTCAATTCMTTTRAGTTT-3', where 'barcode' is an eight-base sequence unique to each sample. PCR reactions were performed from triplicate $20 \mu \mathrm{L}$ mixtures containing $4 \mu \mathrm{L}$ of $5 \times$ FastPfu Buffer, $2 \mu \mathrm{L}$ of $2.5 \mathrm{mM}$ dNTPs, $0.8 \mu \mathrm{L}$ of each primer $(5 \mu \mathrm{M}), 0.4 \mu \mathrm{L}$ of FastPfu Polymerase, and $10 \mathrm{ng}$ of template DNA. 


\section{Illumina MiSeq sequencing}

Amplicons were extracted from 2\% agarose gels and purified using the AxyPrep DNA GelExtraction Kit (Axygen Biosciences, Union City, CA, U.S.) according to the manufacturer' $s$ instructions. After extraction, amplicons were quantified using QuantiFluor $^{\mathrm{TM}}$-ST (Promega, U.S.). Purified amplicons were pooled in equimolar quantities and paired-end sequenced $(2 \times 250)$ on an Illumina MiSeq platform according to standard protocols. The raw reads were deposited into the NCBI Sequence Read Archive (SRA) database (Accession Number: SRP******).

\section{Sequence data processing}

Raw fastq files were demultiplexed and quality-filtered using QIIME (version 1.17) according to the following criteria: Operational Units (OTUs) were clustered using UPARSE (version $7.1 \mathrm{http}: / /$ drive5.com/uparse/) and a 97\% similarity cutoff. Chimeric sequences were identified and removed using UCHIME. The phylogenetic affiliation of each 16S rRNA gene sequence was determined through comparisons with the Silva (SSU115) 16S rRNA database using RDP Classifier (http://rdp.cme.msu.edu/) and a confidence threshold of 70\% (Amato et al., 2013).

\section{Data analysis}

Treatment effects were tested for through analysis of variance (ANOVA) using SPSA17.0, and differences among treatments were compared using Duncan's multiple range test $(\mathrm{P}<0.05)$. The community richness index and community diversity index were calculated as well as data preprocessing, operational taxonomic unit-based analysis and hypothesis tests were performed using mothur (http://www.mothur.org/). The histogram was created using OriginPro 10.1. Variation in community composition across the different treatments as analyzed using a principal coordinate analysis (PCoA) performed using CANOCO 4.5. Multivariate analyses investigating the relationships between environmental variables $\left(\mathrm{OM}, \mathrm{TN}\right.$, available $\mathrm{P}, \mathrm{NH}_{4}$, and $\left.\mathrm{pH}\right)$ and community composition were performed through a redundancy analysis (RDA) using CANOCO 4.5. The RDA invoked a manual forward-selection procedure to identify the significance of environmental variables $(\mathrm{P}<0.05)$ using a Monte Carlo test.

\section{Results \\ Continuous cropping with two crops in a monoculture system caused Chinese cabbage root disease and decline of yield}

Plasmodiophora brassicae Woron is a slime fungus. The dormant sporangia forms in the host cell, spherical or ovate, thin, colorless, single cell, size 4.6 to $6.0 \times 1.6$ to 4.6 $(\mu \mathrm{m})$, germination produces swimming spores. The Spore is pear-shaped or spherical, 2.5 to $3.5 \mu \mathrm{m}$ in diameter. From the root hair of cabbage to the host cell, after a series of evolution and expansion, it enters the formation layer from the root cortex, stimulates the division and expansion of the host parenchyma cells, causing the root system to form a tumor, and finally the pathogen forms a large number of dormant sporangia in the host cell. After the tumor decays, dormant sporangia enter the soil for wintering. Bacteria hibernate sporangia in the soil or adhere to the seeds over the winter, and can survive in the soil for 10 to 15 years. The sporangia spreads through rainwater, irrigation 
water, pests, and agricultural operations, and the germination produces swimming spores that invade the host. After about 10 days, the roots grow tumors. Bacteria can develop at 9 to $30^{\circ} \mathrm{C}$, with a suitable temperature of $23^{\circ} \mathrm{C}$, a suitable relative humidity of $50 \%$ to $98 \%$, and a suitable $\mathrm{pH} 6.2$. Soil water content is less than $45 \%$ and $\mathrm{pH}$ is greater than 7.2 or more, then pathogenic bacteria die. The disease first appears scattered in fields, but in successive seasons it will infect the entire field, reducing the yield significantly of garlic and resulting in no yield at all of cabbage in the CTS treatment (Table 2). The addition of agricultural lime and nutrition management is the common method for its control. But the mechanic of reducing the occurrence of cabbage clubroot in already-infected fields is not clear and this can be discussed in the next sections.

Table 2. Soil properties in different tillage and fertilization treatments

\begin{tabular}{c|c|c|c|c|c|c|c|c}
\hline Treatments & $\begin{array}{c}\mathrm{pH} \\
\left(1: 2.5 \mathrm{H}_{2} \mathrm{O}\right)\end{array}$ & $\begin{array}{c}\text { Total N } \\
(\mathrm{mg} / \mathrm{kg})\end{array}$ & $\begin{array}{c}\text { Total P } \\
(\mathrm{mg} / \mathrm{kg})\end{array}$ & $\begin{array}{c}\text { Available } \\
\mathrm{N}(\mathrm{mg} / \mathrm{kg})\end{array}$ & $\begin{array}{c}\text { Available } \\
\mathrm{P}(\mathrm{mg} / \mathrm{kg})\end{array}$ & $\begin{array}{c}\text { Organic } \\
\text { Matter } \\
(\mathrm{g} / \mathrm{kg})\end{array}$ & $\begin{array}{c}\text { Garlic yield } \\
(\mathrm{t} / \mathrm{ha})\end{array}$ & $\begin{array}{c}\text { Chinese } \\
\text { Cabbage } \\
\text { yield } \\
(\mathrm{t} / \mathrm{ha})\end{array}$ \\
\hline CTS & $5.90 \pm 0.08 \mathrm{e}$ & $1.61 \pm 0.02 \mathrm{c}$ & $1.47 \pm 0.01 \mathrm{~b}$ & $189.06 \pm 5.32 \mathrm{a}$ & $54.4 \pm 0.98 \mathrm{ab}$ & $23.58 \pm 0.27 \mathrm{c}$ & $9.17 \pm 0.05 \mathrm{e}$ & null \\
\hline NTS & $6.98 \pm 0.06 \mathrm{a}$ & $1.90 \pm 0.03 \mathrm{a}$ & $1.52 \pm 0.03 \mathrm{~b}$ & $200.16 \pm 7.65 \mathrm{a}$ & $53.1 \pm 1.23 \mathrm{ab}$ & $37.16 \pm 0.70 \mathrm{a}$ & Null & null \\
\hline EMT & $6.14 \pm 0.07 \mathrm{~d}$ & $1.68 \pm 0.09 \mathrm{bc}$ & $1.48 \pm 0.05 \mathrm{~b}$ & $197.23 \pm 2.31 \mathrm{a}$ & $55.1 \pm 2.69 \mathrm{ab}$ & $25.12 \pm 0.46 \mathrm{c}$ & $12.53 \pm 0.02 \mathrm{~d}$ & $62.5 \pm 4.3 \mathrm{a}$ \\
\hline LIM & $6.57 \pm 0.10 \mathrm{bc}$ & $1.75 \pm 0.06 \mathrm{bc}$ & $1.59 \pm 0.05 \mathrm{ab}$ & $194.43 \pm 6.15 \mathrm{a}$ & $51.3 \pm 1.31 \mathrm{~b}$ & $24.66 \pm 0.30 \mathrm{c}$ & $14.06 \pm 0.12 \mathrm{~b}$ & $69.8 \pm 5.5 \mathrm{a}$ \\
\hline LOF & $6.72 \pm 0.07 \mathrm{~b}$ & $1.78 \pm 0.03 \mathrm{ab}$ & $1.69 \pm 0.06 \mathrm{a}$ & $196.15 \pm 3.98 \mathrm{a}$ & $52.2 \pm 2.32 \mathrm{ab}$ & $25.23 \pm 0.37 \mathrm{c}$ & $15.11 \pm 0.01 \mathrm{a}$ & $74.3 \pm 4.3 \mathrm{a}$ \\
\hline OFT & $6.39 \pm 0.04 \mathrm{c}$ & $1.81 \pm 0.06 \mathrm{ab}$ & $1.69 \pm 0.09 \mathrm{a}$ & $197.45 \pm 4.32 \mathrm{a}$ & $56.4 \pm 1.69 \mathrm{a}$ & $28.69 \pm 1.19 \mathrm{~b}$ & $13.28 \pm 0.19 \mathrm{c}$ & $66.7 \pm 4.1 \mathrm{a}$ \\
\hline $\begin{array}{c}\text { ANOVA } \\
\text { P-Values }\end{array}$ & $<0.001$ & $<0.001$ & $<0.001$ & $<0.001$ & $<0.001$ & $<0.001$ & $<0.001$ & $<0.001$ \\
\hline
\end{tabular}

NTS represents untilled soil, CTS represents continuously tilled soil, OFT represents organic fertilizer treatment, LOF represents quicklime and organic fertilizer treatment, LIM represents quicklime treatment, EMT represents effective microorganisms treatment. Values are mean \pm standard deviation $(n=3)$. Values within the same column followed by the different letters indicate significant difference (Duncan's multiple range test $(\mathrm{P}<0.05)$ )

\section{Effects of continuous ecological factors controlling on soil chemical properties}

In this content, the soil conditioners controlling (Lime, EM, bio-organic fertilizer) significantly influenced $(\mathrm{P}<0.05)$ soil properties including soil $\mathrm{pH}$, the concentration of $\mathrm{TN}, \mathrm{OM}$ and so on (Table 2). Soil $\mathrm{pH}$ of the CTS treatment was significantly lower than for all other treatments, with the greatest difference $(18.3 \%)$ occurring between the CTS treatment and NTS treatment. Compared with the CTS, all the fertilizer and regulators treatments significantly increased the garlic yield and total $\mathrm{N}$, whereas $\mathrm{TP}$, available $\mathrm{P}$, available $\mathrm{N}$ and OM did not significantly differ among CTS, EMT, and LIM. There was no significant difference observed among all treatments for the Chinese cabbage yield. Changes to soil properties may affect soil enzyme activities and the composition and abundance of bacterial communities, which were further examined using qPCR techniques and the Illumina MiSeq platform.

\section{Soil enzyme activities}

Soil enzyme activities were significantly influenced by soil depth (Figure 1). The EMT treatment had a particularly strong stimulatory effects on PPO, URE, and SUC activities, achieving $89.7 \%, 15.4 \%$, and $11.4 \%$ increases in activity respectively in shallow soil layer $(0-20 \mathrm{~cm})$ when compared with activities in the same soil layer for the 
CTS treatment. Likewise, Lime and organic fertilizer boosted URE, SUC, and PPO activities. The NTS treatment increased URE, SUC, and PPO activities, resulting in a $53.0 \%, 54.7 \%$, and $183.4 \%$ increase in activity, respectively, in the shallow soil layer (0$20 \mathrm{~cm}$ ), when compared with activities in the same soil layer for the CTS treatment. On the other hand, the CTS treatment stimulated CAT activity by $49.0 \%$ compared to under the NTS treatment. Among all treatments, URE and PPO activities were highest under the LOF treatment, where they were $3.84 \%$ and $22.5 \%$ greater, respectively than under the OFT. The URE and PPO activities under the LOF treatment were also 6.96\% and $33.7 \%$ higher, respectively than under the LIM treatment. Under the LIM treatment, SUC activity was $2.90 \%$ and $6.46 \%$ greater than under the LOF and OFT, respectively. Under the OFT, SUC activity was $9.22 \%$ higher than under the EMT. CAT activity was highest under the EMT, followed by LIM, OFT, and then LOF.

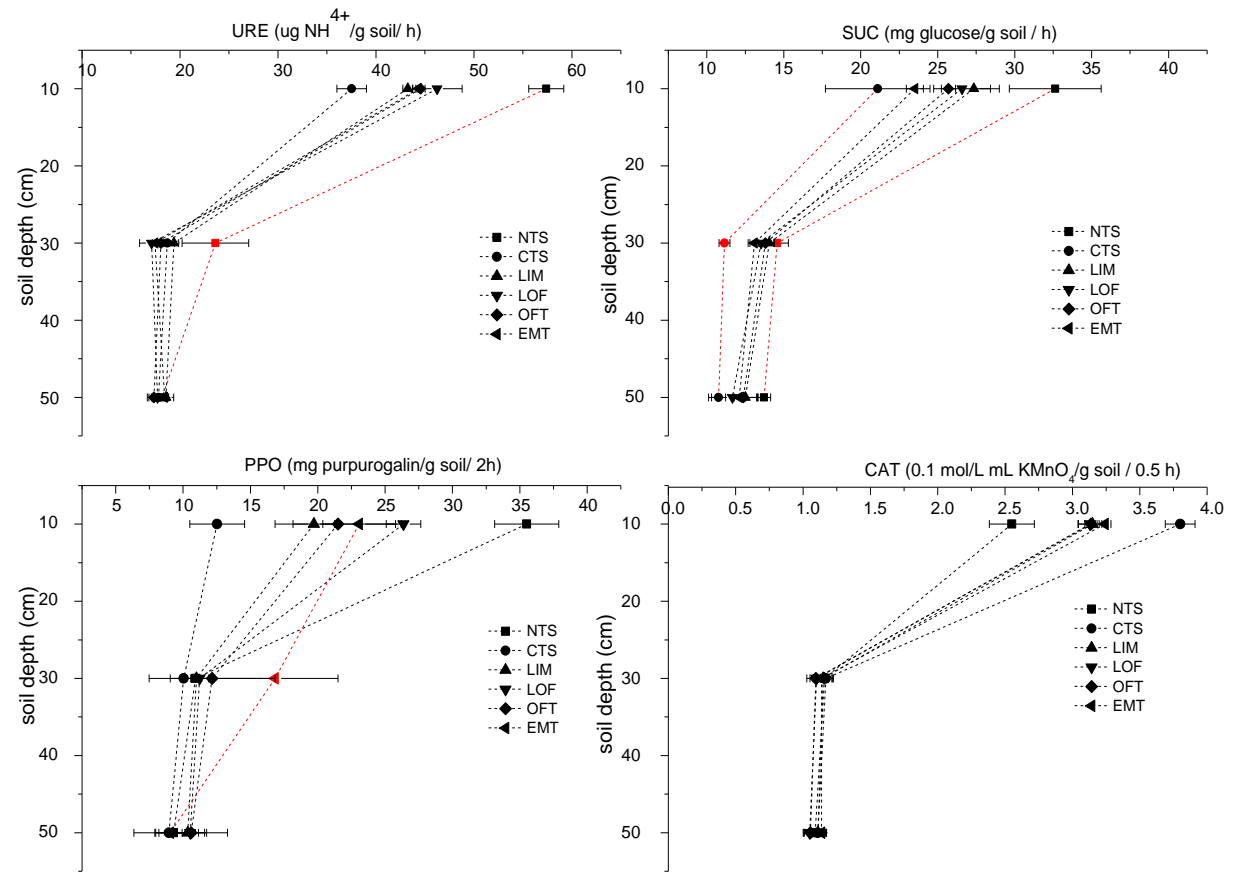

Figure 1. Soil URE, SUC, PPO, CAT activities depending on soil depth and different treatments. Errors bars represent standard error $(n=3)$

The activities of URE, SUC and PPO were consistently higher in the shallow soil layer $(0-20 \mathrm{~cm})$ than in the middle $(20-40 \mathrm{~cm})$ or deep layer $(40-60 \mathrm{~cm})$. SUC activity in $20-40 \mathrm{~cm}$ soil layer was $29.9 \%$ higher than in the $40-60 \mathrm{~cm}$ soil layer. Within the middle soil layer (20-40 cm), SUC activity was highest under the NTS treatment, followed, in order of decreasing SUC activity by LIM, OFT, LOF, EMT, and then CTS. The activities of SUC, PPO, and CAT did not significantly differ between the middle and deep soil layers.

In the shallow soil layer, the soil enzyme activities significant correlated with the soil chemical properties (see Table Al). There was a positive correlation between the activities of hydrolytic enzymes and $\mathrm{pH}$ and total $\mathrm{N}$. We also found significant reductions in catalase activity with increasing levels of organic matter and total $\mathrm{N}$. 


\section{Microbial C and $N$}

Different treatments caused a shift of the soil microbial biomass carbon and nitrogen in soil samples (Figure 2). The organic fertilizer and EM inoculant addition increased $\mathrm{C}_{\text {mic }}$ and $\mathrm{N}_{\text {mic }}$ contents relative to the CTS, EM inoculant addition resulted in the highest soil $\mathrm{C}_{\text {mic }}$ and $\mathrm{N}_{\text {mic }}$ contents. The addition of the organic fertilizer did increase $\mathrm{C}_{\text {mic }}$, but $\mathrm{N}_{\text {mic }}$ in the LOF treatment was higher than the OFT treatment under the same input of organic fertilizer. In this study, the $\mathrm{C}_{\text {mic }} / \mathrm{N}_{\text {mic }}$ ratio was the highest in the treatments of CTS and LIM followed by the OFT and EMT; the other two treatments were significantly lower (Figure 2). Fertilizer input type and soil $\mathrm{pH}$ showed significant impacts on $\mathrm{C}_{\text {mic }}, \mathrm{N}_{\text {mic }}$ and $\mathrm{C}_{\text {mic }} / \mathrm{N}_{\text {mic }}$ ratio. The higher rate of input significantly increased both $\mathrm{C}_{\text {mic }}$ and $\mathrm{N}_{\text {mic }}$ and decreased the $\mathrm{C}_{\text {mic }} / \mathrm{N}_{\text {mic }}$ ratio. There was a significant interaction between input type and level for $\mathrm{C}_{\text {mic }}$ and $\mathrm{C}_{\mathrm{mic}} / \mathrm{N}_{\text {mic }}$.

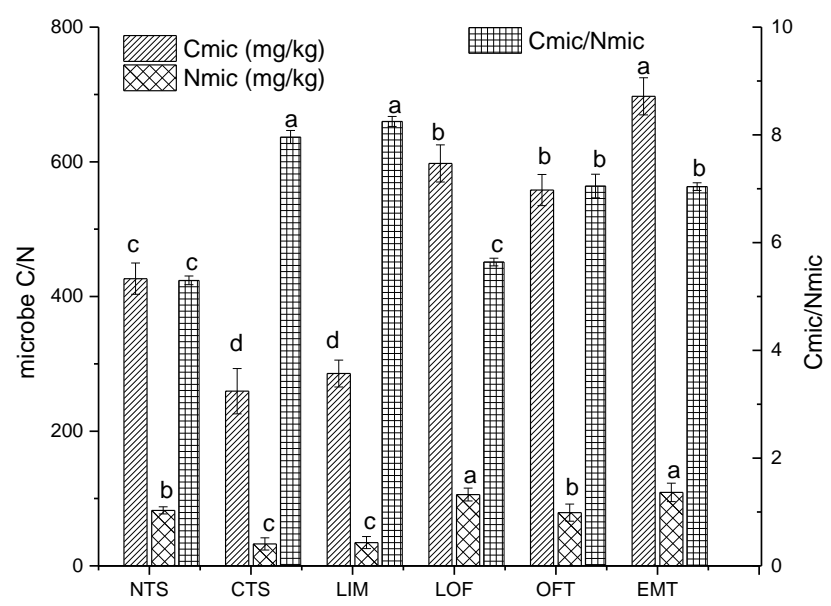

Figure 2. Soil microbial biomass (Cmic and Nmic) in different treatments determined by the chloroform-fumigation-extraction method. Error bars indicate the standard deviation of relative biomass between three duplicate samples. The same column followed by the different letters indicate significant difference ( $L S D, P<0.05)$

\section{Bacterial community composition and diversity}

After two years of soil nutrition management 16S rRNA high-throughput sequencing showed bacterial community profiles to markedly differ among treatments. The Illumina-based analysis of the V3 region of the 16S rRNA gene resulted in recovery of 118, 101 high quality sequences from the six soil treatments (Table 3). More than 17,000 valid reads were obtained for each replicate through a sequence optimization process, and the bacterial community richness index was calculated. After quality control filtering, median sequence length of each read was 396 bp (Table A2). The Good' s coverage values (Table 3 ) exceeded $98 \%$ at a $97 \%$ similarity cutoff, indicating that sequence reads were sufficient to capture the bacterial diversity within these soils. Based on Mothur clustering, the number of OTUs within soil samples ranged from 9191364, depending on treatments. The lowest number of total OTUs was observed under the NTS treatment. The highest Shannon and Chao 1 indices occurred under the EMT and OFT treatments, which suggested that bio-organic fertilizer facilitated bacterial community diversity. Rank-abundance curves can be used to explain species abundance 
and evenness of species distribution. The Rank-abundance curves for the six soil samples were shown in Figure 3, and it can be seen that these six curves were not flat at the end, which reflected the uneven distribution of species. The asymptote of the OFT, EMT, and LIM treatment curves appeared to occur at higher $\mathrm{x}$-axis values than that of the NTS treatment curve, which indicated that bacterial community abundance in the treatments of OFT, EMT, and LIM treatments were significantly higher than the treatment of NTS. The highest bacterial abundance occurred in the treatment of OFT. Thus, two-year continuous controlling cropping increased the bacteria community diversity.

Table 3. Summary of the pyrosequencing sequencing data and diversity estimates

\begin{tabular}{c|c|c|c|c|c}
\hline \multirow{2}{*}{ Sample } & \multirow{2}{*}{ Number of reads } & \multicolumn{4}{|c}{ 97\% sequence identity } \\
\cline { 3 - 6 } & & Number of OTUS & $\begin{array}{c}\text { Good's coverage ratio } \\
\text { C(\%) }\end{array}$ & $\begin{array}{c}\text { Shannon index } \\
\text { (H') }\end{array}$ & $\begin{array}{c}\text { CHAO1 } \\
\text { estimator }\end{array}$ \\
\hline CTS & 17450 & 1179 & 98.6 & 5.92 & 1393 \\
EMT & 17209 & 1287 & 98.5 & 6.12 & 1445 \\
LIM & 19993 & 1285 & 98.9 & 5.95 & 1427 \\
LOF & 19048 & 1199 & 98.6 & 5.43 & 1397 \\
NTS & 26386 & 919 & 99.4 & 4.82 & 1032 \\
OFT & 18015 & 1364 & 98.5 & 6.19 & 1558 \\
\hline
\end{tabular}

Chao: community richness, Coverage: sampling coverage, Shannon: community diversity

Rank-abundance distribution curve

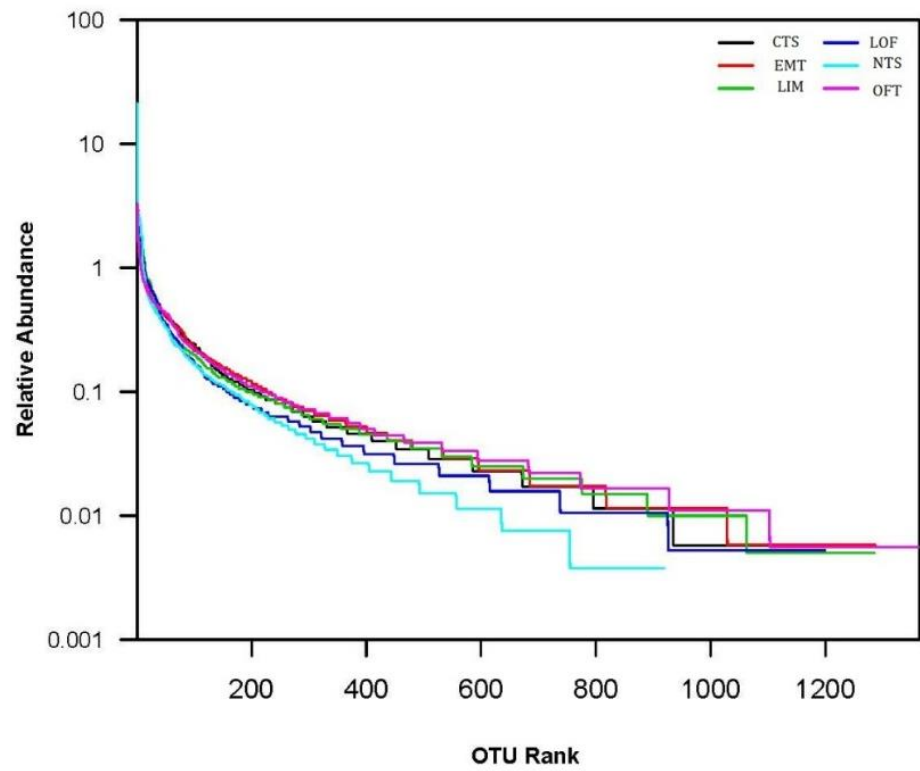

Figure 3. OTU Rank-abundance curves for the OTUs in the soil samples of different treatments

All sequences were classified into 51 phyla or groups using Mothur program. The overall bacterial composition was relatively consistent across treatments, whereas the distribution of each phylum or group varied among treatments (Figure 4). Under all treatments, Proteobacteria, Acidobacteria, Bacteroidetes, Planctomycetes, and Actinobacteria were the five most dominant phyla, accounting for $>70 \%$ of the total 
reads. Significantly more unclassified species were detected under the CTS, EMT, LIM, LOF, and OFT treatments, which was in accordance with the higher diversity indices for these treatments. Compared with the other treatments, soils from the EMT had significantly higher percentages of Actinobacteria (1.3-6.5-fold), Armatimonadetes (1.2-7.3-fold), WA3 (1.0-4.8-fold), and Chlorobi (1.6-34.5-fold), and lower percentages of Planctomycetes (CTS: 5.6\%, EMT: 5.1\%, LIM: 5.8\%, NTS: 6.8\%, LOF: $3.8 \%$, and OFT: $6.1 \%$ ). The percentages of Actinobacteria and Firmicutes were lowest in soils from the LOF treatment. More Cyanobacteria were detected in soils from the CTS treatment than from the LIM or LOF treatments, and the lowest number of Cyanobacteria was found in soil from the NTS treatment. A higher percentage of Lysobacter was found in NTS than it in other treatments. All fertilization treatments significantly impacted bacterial community structure. The abundance of Lysobacter, RB41, Steroidobacter, and Planctomycetaceae was lower in the NTS than in the LOF treatment soil. Compared with the CTS, Xanthomonas, Oxalobacteraceae, Lineage_IIb, and Nitrospira relative abundances increased in the EMT and OFT treatment soils, whereas Haliangium and Sphingomonas relative abundances decreased under these two treatments. The relative abundance of all 50 detected genera is listed in Table A3. Lysobacter, Rhodospirillaceae, Comamonadaceae, KCM-B-112, Xanthobacteraceae, and Sporocytophaga abundances were significantly greater in NTS treatment soil compared with CTS treatment soil, whereas Acidobacteriaceae, Arenimonas, Sorangium, Rhizobium, Lineage_IIb, and Flavobacterium abundances were higher in CTS than in NTS.

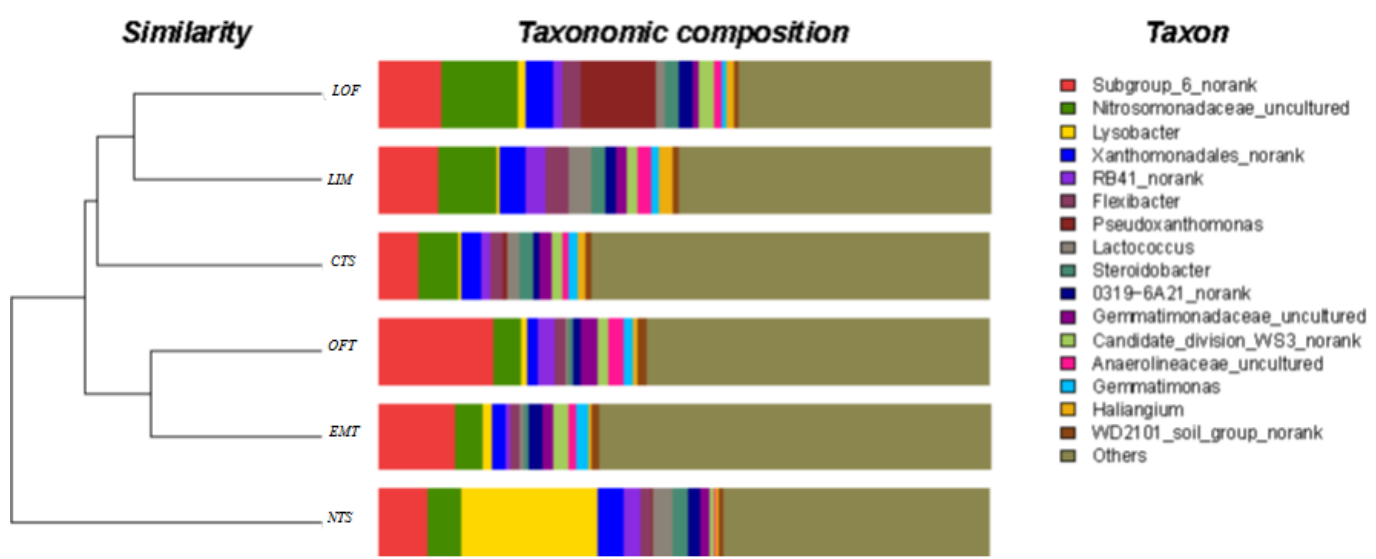

Figure 4. Comparison of the bacterial communities at the gene level. The branch structure is used to describe and compare similarities and differences between multiple treatments. The hierarchical clustering according to beta diversity distance matrix (Hierarchical clustering) analysis. A tree structure was constructed by using the unweighted pair group method with arithmetic mean (UPGMA) algorithm

On a genus level, all 412 detected genera were observed in soils from all treatments, except for Xanthomonas, which was not detected in NTS or LIM treatment soils, and Sporocytophaga, which was not detected in EMT or LOF treatment soils. Results of the cluster analysis for the 100 most abundant genera (assessed through counts of OTUs) within soil samples from the six treatments are displayed on a heatmap (Figure A3). Soils from the six treatments were classified into two groups (continuous cropping and untilled soil) according to their bacteria genera composition (Figure 4). The continuous 
cropping group (EMT, OFT, CTS, LIM, and LOF) subdivided into a bio-fertilizer and non-bio-fertilizer group. The untilled soil group was made up of only the NTS treatment. The taxonomic information for the OTUs was used to develop the phylogeny. The phylogenetic classification was used to analyze the relationships between microbial ancestry and abundance within soil samples from the different treatments.

In order to further investigate bacterial community composition among the different treatments, we performed a PCoA on the relative abundance of bacterial genera (Figure 5). Data are presented as a 2D plot to better illustrate the relationships. The PCoA clearly separated CTS from NTS. Values for LIM, LOF, EMT, and OFT grouped together along the PC1 axis. Although EMT and OFT were relatively similar, the different bio-organic fertilizer significantly affected the soil microbial community. NTS had a significantly higher PC1 value, and EMT had a higher PC2 value than other treatments.

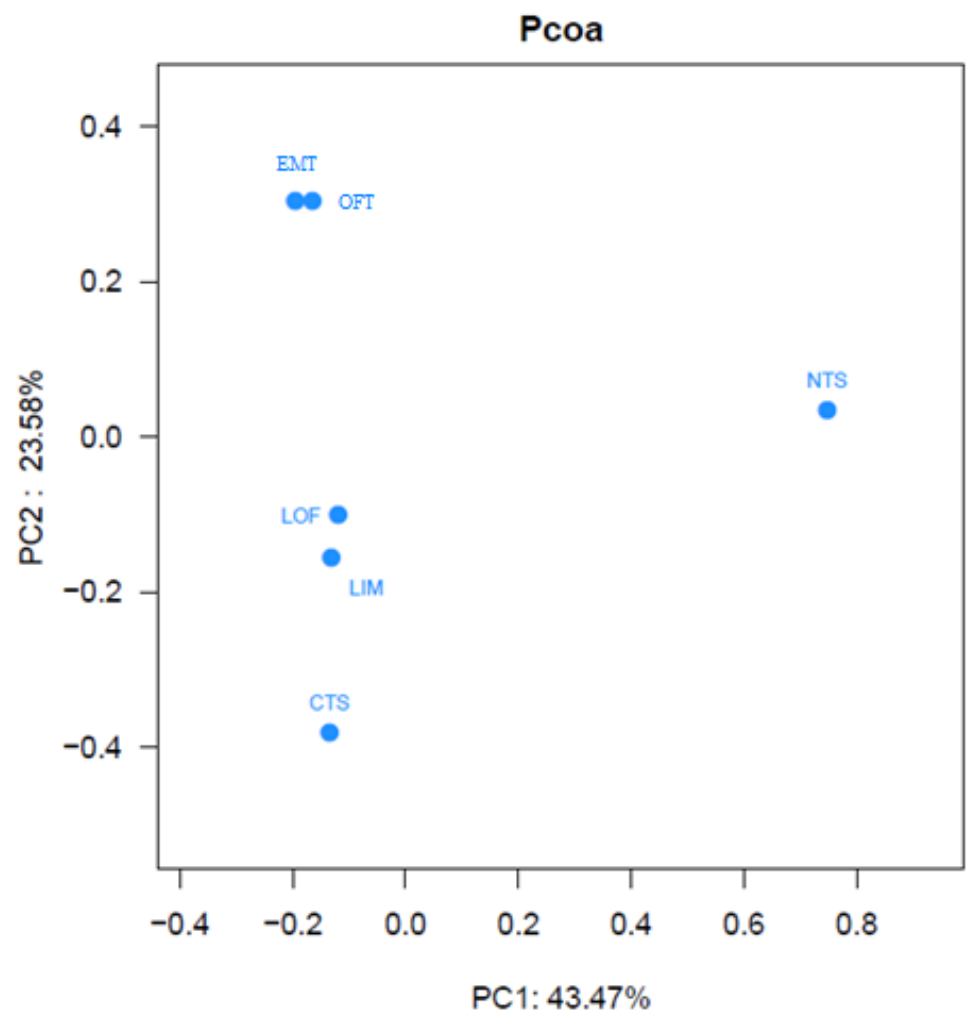

Figure 5. Principal co-ordinates analysis (Pcoa) on the relative abundance of bacterial genera. Principal components (PCs) 1 and 2 explained $43.47 \%$ and $23.5 \%$ of the variance, respectively

\section{Relationships between bacterial community composition and environmental variables}

According to the forward-selection CANOCO, soil organic matter and total $\mathrm{N}$ concentration, which accounted for $27.4 \%$ and $1.75 \%$ of the variation in bacteria community composition, were the two most important contributors to the variation among bacterial communities (Figure 6). All environmental variables together explained $79.3 \%$ of the variation in microbial communities composition among treatments. The soil properties, in order of decreasing influence on the bacterial community composition were: $\mathrm{OM}, \mathrm{TN}, \mathrm{GY}, \mathrm{TP}, \mathrm{pH}, \mathrm{CCY}$, available $\mathrm{N}$, available $\mathrm{P}$. 
The correlation (or covariance, depending on the standardization option used in the analysis) between phyla and environmental variables can be approximated through projections of two perpendicular vectors, representing each of the phyla and environmental variable. Most of the abundant phyla were significantly correlated with at least one environmental factor. However, Sphingomonas, Nitrospira, Haliangium, Myxococcales, Flexibacter, and Nitrosomonadaceaewere did not significantly correlated with any of the environmental factors. The abundances of Chitinophagaceae, Aquicella, Xanthomonadales, Solimona, Bacillus, Gaiella, Piscinibacter, Gemmatimonadaceae were positively correlated with soil TN, OM, pH, and available N, whereas Planctomycetaceae, Comamonadaceae, Lysobacter, Xanthobacteraceae, and Sporocytophaga were positively correlated with TP. The phylum was correlate with garlic yield and Chinese cabbage yield, for some orders, such as Nitrosomonadaceae, Haliangium, Flexibacter, etc.

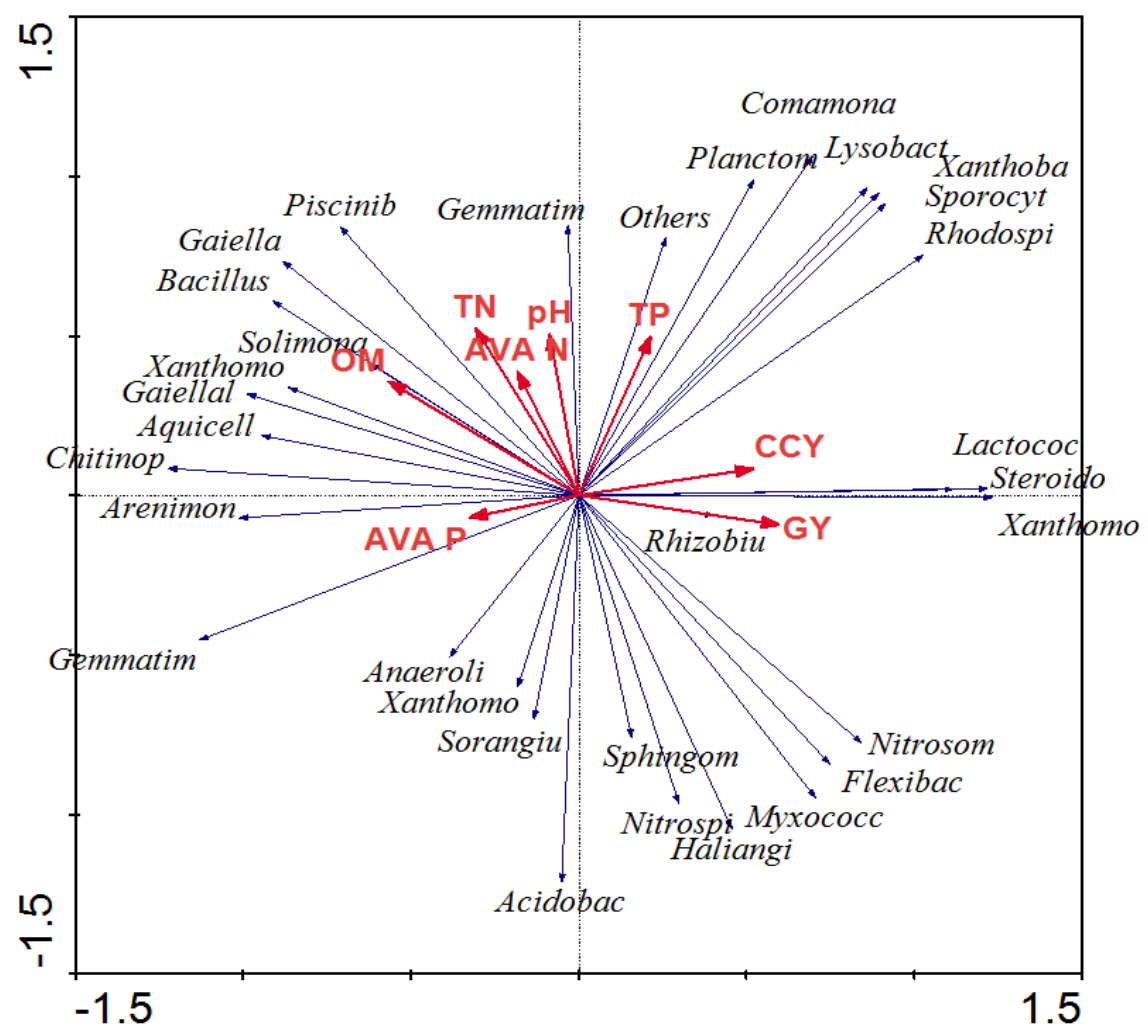

Figure 6. RDA of soil bacterial communities and soil characteristics for each treatment. Soil factors indicated in red line include AVA P (available phosphorus), AVA N (available N), OM (organic matter), TN (total nitrogen), TP (total phosphorus), GY (garlic yield), CCY (Chinese cabbage yield), $\mathrm{pH}$

\section{Discussion}

This research approach provides insight into how soil chemical and biological properties, total bacterial community structure and soil extracellular enzyme activities respond to the contrasting lime, bioorganic fertilizer and EM to control and suppress the clubroot. Short -term soil conditioners significantly impacted soil nutrient availability, and in turn affected soil microbial community structure and function. Bacterial 
community diversity, biomass and enzyme activities involved in nutrient transformations were enhanced in treatments receiving annual applications of soil conditioners and chemical fertilizers.

\section{Continuous cropping with two crops in a monoculture system caused root disease and decreased soil nutrient levels and $\mathrm{pH}$}

This Clubroot is a major issue when brassica crops are grown in short rotations (McGrann et al., 2016). Clubroot has spread rapidly across the major Chinese brassica growing regions and become established as a serious threat to production (Shakeel et al., 2016).

Many indicators of soil quality can be manipulated through long-term raw manure and mineral fertilization under monoculture continuous cropping systems. Continuous cultivation over 35 years can cause reductions in soil $\mathrm{pH}$, TN, and OM compared with NTS treatment soil. Long-term raw manure fertilizer application and monoculture cropping can decrease soil $\mathrm{pH}$ (Wang et al., 2015). Previous studies have found the magnitude of raw manure fertilization effects on microbial biomass to be $\mathrm{pH}$-dependent, which agrees well with the results reported in this study. This was also observed in our trial where microbial biomass increased with amendments application rate, regardless of the input type (Figure 2). The mechanism underlying declines in $\mathrm{pH}$ and nutrient levels with long-term monoculture cropping may be an accumulation of organic acids caused by repeated raw manure application, and leading to that in an accumulation of organic acids which decrease the ability to keep water and fertilizer deteriorated soil structure. This is consistent with the previous reports (Gaind and Singh, 2016). In this case, the similar effects on available nutrients can be concluded from the data. These findings suggest that soil $\mathrm{pH}$ influenced microbial activity resulting in different rates of $\mathrm{N}$ and $\mathrm{P}$ mineralized, which is supported by the variation in activities of enzymes involved in $\mathrm{N}$ and $\mathrm{P}$ cycling (e.g. urease and phosphatase) observed in this study.

\section{Effects of soil amendments on soil pH and nutrients}

It is difficult to control clubroot because the pathogen survives long periods in the soil for a long time as resting spores. Previous research has provided evidence that soil $\mathrm{pH}$ can influence clubroot, and liming arose as a conventional technique to control the clubroot through its influences on soil pH (Chai et al., 2014).

Niwa et al. (2007) found neutralization of soil using $\mathrm{Ca}(\mathrm{OH})_{2}$ and $\mathrm{CaCO}_{3}$ to suppress clubroot infections. Clubroot is suppressed effectively under soil of neutral $\mathrm{pH}$ in the presence of calcium, which has led to the hypothesis that either spore germination or root-hair infection, each part of the primary phase of the clubroot life cycle, is inhibited under such conditions (Niwa et al., 2008). In addition to these abiotic factors, it has been suggested that the microbial community can contribute to clubroot suppression. Ruaro et al found a negative correlation between severity of clubroot infection and foliage $\mathrm{N}, \mathrm{Ca}, \mathrm{Mg}$, and $\mathrm{B}$ concentrations and a reduction in infection when soil was adjusted to $\mathrm{pH} 6.5$ and treated with calcium nitrate (Ruaro et al., 2009). Therefore, in soils with abundant nutrients and nearly neutral $\mathrm{pH}$ levels, the infection of host plants with the clubroot fungus is suppressed. In this case, $\mathrm{pH}$ and total $\mathrm{N}$ and $\mathrm{SOM}$ content increased markedly contrasted in LOF, OFT and EMT. Available nutrient and carbon concentrations affected the physiology of the host plant and subsequent disease development. 


\section{Soil amendment strategies increased bacterial richness and enzyme activities}

Otherwise the untilled soil(NTS), contrasted with infected soil(CTS, LIM, LOF, EMT and OFT), is healthy and retained higher biomass. In terms of microbial activity, functional diversity was suppressed in the diseased soil samples. Activities of soil enzymes, including urease, phosphatase, and sucrose, were also reduced in infected soils. Soil urease, phosphatase, and catalase activities were determined in order to assess the potential turnover rates of soil carbon and nitrogen (Zhang et al., 2016). Enzymatic activities in diseased soils were inhibited by 45.1 to $169.2 \%$ in the LOF, EMT, OFT, LIM and CTS. In our study, the higher soil microbial biomass under the EM and organic fertilizer treatments may have been due to the addition of microbial population in the treatment and the additional $\mathrm{C}$, which activates the soil indigenous microbiota. The lime was added into the infected soil that resulted in the increased $\mathrm{pH}$ and induced the bacterial growth. Our results corroborated findings of previous researchers. They have suggested lime and bio regulators can stimulate enzyme activities (Shrestha et al., 2015). We also found soil amendments to infected soil altered soil $\mathrm{pH}$ and available nutrients in favor of increasing top soil enzymatic activities and bacterial richness. It was interesting to note that we observed greater increases to soil $\mathrm{pH}$ through organic fertilizer application than previous studies. This suggests a threshold effect of the influences of ecological factors on enzyme activities and bacterial biomass in diseased soils (Lagerlof et al., 2015). The activity of Polyphenol oxidase was significantly higher than other treatments in the top soil. Polyphenol oxidase (PPO) is an extremely effective soil acidity and nutrient modifier. Studies have shown that PPO can contribute to pathogen resistance, especially resistance to opportunistic pathogens. Another potential effect of PPO is elevated oxidative stress in the soil (Yakushev et al., 2014). Previous researchers have suggested that potential enzyme synthesis rates were determined by microbial community composition. Although further research on the relationships between individual microorganism species, functional activities, and soil-borne pathogens is required, our results provide strong evidence of links between the microbial community composition and functional activities.

\section{Soil amendment strategies changed bacterial community compositions}

Many factors may affect the structure and function of bacterial communities within the rhizosphere soil (Simmons et al., 2016). In our study, the Chao 1 index, which is representative of bacterial phylotype richness levels, showed healthy soil (NTS) to have the highest bacterial diversity among the six treatments (Table 3). Diseased soil had lower bacterial richness than healthy soil. The phylum assignment results identified $99.99 \%$ of the $16 \mathrm{~S}$ rRNA sequence reads as bacteria belonging to 16 phyla; Lysobacter was the dominant phylum in the healthy soil samples (NTS) (Figure 4). The Xanthomonadaleand Bacillus phyla were significantly more abundant in healthy rhizosphere soil than in diseased soil $(\mathrm{P}<0.05)$. Otherwise, the abundances of the Gemmatimonas, Acidobacteriaceae, Sorangium, and Rhizobium phyla were higher in diseased samples (CTS) (Table A3). These results suggest that that the bacterial community structures were similar in diseased and healthy soils. Lysobacter and Xanthomonadale, two mainly species within the Stenotrophomonas genus were multidrug-resistant opportunistic pathogens (Dhawan et al., 2016). This was interesting because it was generally accepted that these phyla are sensitive to changes in nutrient levels. Our results provided strong evidence that these phyla respond to soil-borne 
pathogens when the rhizosphere soil was amended, although mechanisms underlying this process were not addressed in this study. Kobayaschi et al. (2011) have also shown Lysobacterto possess antifungal properties, specifically against Phytophthoracapsici, a destructive pathogen of pepper plants (Ko et al., 2009). Previous studies have concluded that shifts in soil microbial community abundance and composition can significantly influence nutrient cycle dynamics and improve resistance to pathogens (ChavezRomero et al., 2016). Therefore manipulations of soil acidity to a suitable $\mathrm{pH}$ and addition of organic manure can effectively improve soil resistance to various pathogens.

\section{Relationships between soil properties and bacterial community composition}

We hypothesized that populations of bio-control bacteria will be stimulated by adjusting the content of different substrate in soil so as to reduce the number of pathogens microbial and achieve the goal of preventing risk of cabbage infected by pathogen. Our hypothesis could be proved by the results of recent two years trial experiment (see Figure 4). The observed changes to bacterial community composition can be explained by the strong influences of soil amendments on soil chemistry, such as nutrients bioavailability. The higher $\mathrm{TN}, \mathrm{pH}$ and $\mathrm{OM}$ in the surface layer soil significantly increased these bacterial phylotype richness compared with untilled soil. Similar effects were seen for total phosphorus and plant yield (Figure 6). These results may be explained by effects of different $\mathrm{C}$ substrates on host plants (Bergkemper et al., 2016). Another mechanism through which soil bacterial communities can be modified is resource availability. Large amounts of antibiotics were introduced to the soil environment with manure amendment, and a previous study showed cow manure to shift the bacterial community structure in clay soil (Fernandez et al., 2016). The relative abundance of antibiotic bacteria (Xanthomonadales, Lysobacter, Pseudomonas, and Bacillus) present within the soils treated with the bio-organic fertilizer was greater than for the soils treated with lime because of the greater organic matter and total nitrogen content of the bio-organic fertilizer. These results were similar to the observation of a previous study (Wang et al., 2016). The cause of antibiotic resistance is multifaceted, including over use, inappropriate use, and regulatory incompetence, and results in a deficiency of useful antibiotics for clinical use. The results of this study suggest that bio-organic fertilizer can be used to suppress crop pathogens.

\section{Conclusions}

Severity of brassica crop infection with clubroot is known to be linked to $\mathrm{pH}$ and soil nutrient content. Soil amendments, which raise $\mathrm{pH}$ and/or soil nutrients content, can be applied to control clubroot infection of vegetable brassica crops and manipulate bacterial community abundance and composition. The results of this study provide important insights into the influences of soil amendment strategies on the microbial community structure within monoculture agricultural systems and identify the major factors shaping microbial communities. Therefore, further research focuses on revealing the relationship between soil microbial diversity and function, and establishing a direct and quantitative relationship between soil microbial diversity and function. And the relationship between soil microbial diversity and pathogenic function of pathogenic bacteria could been revealed furtherly. 
Acknowledgements. The authors thank the many farmers and advisors who sent samples for tests in this project as well as the many staff members at NEAU who assisted. This project was funded by a research grant from the National Key Technology R\&D Program (2017YFD0300503), and the Applied Basic Research Programs of Science and Technology Commission Foundation of Heilongjiang Province (No. GC13B111).

\section{REFERENCES}

[1] Amato, K. R., Yeoman, C. J., Kent, A., Righini, N., Carbonero, F., Estrada, A., Gaskins, H. R., Stumpf, R. M., Yildirim, S., Torralba, M. (2013): Habitat degradation impacts black howler monkey (Alouatta pigra) gastrointestinal microbiomes. - The ISME journal 7: 1344.

[2] Bergkemper, F., Welzl, G., Lang, F., Kruger, J., Schloter, M., Schulz, S. (2016): The importance of $\mathrm{C}, \mathrm{N}$ and $\mathrm{P}$ as driver for bacterial community structure in German beech dominated forest soils. - J Plant Nutr Soil Sc 179: 472-480.

[3] Chagnon, P.-L., Bradley, R. L. (2013): Evidence that soil nutrient stoichiometry controls the competitive abilities of arbuscular mycorrhizal vs. root-borne non-mycorrhizal fungi. - Fungal Ecology 6: 557-560.

[4] Chai, A. L., Xie, X. W., Shi, Y. X., Li, B. J. (2014): Special Issue: Research status of clubroot (Plasmodiophora brassicae) on cruciferous crops in China. - Can J Plant Pathol 36: 142-153.

[5] Chavez-Romero, Y., Navarro-Noya, Y. E., Reynoso-Martinez, S. C., Sarria-Guzman, Y., Govaerts, B., Verhulst, N., Dendooven, L., Luna-Guido, M. (2016): 16S metagenomics reveals changes in the soil bacterial community driven by soil organic $\mathrm{C}, \mathrm{N}$-fertilizer and tillage -crop residue management. - Soil Till Res 159: 1-8.

[6] Chen, X. L., Wang, Y. F., Li, W. Q., Wang, Y., Wei, D., Wang, X. J., Han, X. Z. (2015): Impact of long-term continuous soybean cropping on ammonia oxidizing bacteria communities in the rhizosphere of soybean in Northeast China. - Acta Agr Scand B-S P 65: 470-478.

[7] Dhawan, B., Sebastian, S., Malhotra, R., Kapil, A., Gautam, D. (2016): Prosthetic joint infection due to Lysobacter thermophilus diagnosed by 16S rRNA gene sequencing. Indian J Med Microbi 34: 100-102.

[8] Diaz, P. I., Dupuy, A. K., Abusleme, L., Reese, B., Obergfell, C., Choquette, L., DongariBagtzoglou, A., Peterson, D. E., Terzi, E., Strausbaugh, L. D. (2012): Using high throughput sequencing to explore the biodiversity in oral bacterial communities. - Mol Oral Microbiol 27: 182-201.

[9] Dowling, A., O'Dwyer, J., Adley, C. C. (2015): Lime in the limelight. - J Clean Prod 92: 13-22.

[10] Fernandez, A. L., Sheaffer, C. C., Wyse, D. L., Staley, C., Gould, T. J., Sadowsky, M. J. (2016): Structure of bacterial communities in soil following cover crop and organic fertilizer incorporation. - Appl Microbiol Biot 100: 9331-9341.

[11] Forster, J. C. (1995): 3 - Soil sampling, handling, storage and analysis A2 - Alef, Kassem. - In: Nannipieri, P. (ed.) Methods in Applied Soil Microbiology and Biochemistry. Academic Press, London, pp. 49-121.

[12] Fukuta, S., Tamura, M., Maejima, H., Takahashi, R., Kuwayama, S., Tsuji, T., Yoshida, T., Itoh, K., Hashizume, H., Nakajima, Y., Uehara, Y., Shirako, Y. (2013): Differential detection of Wheat yellow mosaic virus, Japanese soil-borne wheat mosaic virus and Chinese wheat mosaic virus by reverse transcription loop-mediated isothermal amplification reaction. - J Virol Methods 189: 348-354.

[13] Gaind, S., Singh, Y. V. (2016): Soil organic phosphorus fractions in response to long-term fertilization with composted manures under rice-wheat cropping system. - J Plant Nutr 39: 1336-1347. 
[14] Glaser, K., Kuppardt, A., Boenigk, J., Harms, H., Fetzer, I., Chatzinotas, A. (2015): The influence of environmental factors on protistan microorganisms in grassland soils along a land-use gradient. - Sci Total Environ 537: 33-42.

[15] Kandeler, E., Stemmer, M., Palli, S., Gerzabek, M. H. (1999): Xylanase, Invertase and Urease Activity in Particle - Size Fractions of Soils. - In: Berthelin, J., Huang, P. M., Bollag, J. M., Andreux, F. (eds.) Effect of Mineral-Organic-Microorganism Interactions on Soil and Freshwater Environments. Springer US, Boston, MA, pp. 275-286.

[16] Ko, H. S., Jin, R. D., Krishnan, H. B., Lee, S. B., Kim, K. Y. (2009): Biocontrol Ability of Lysobacter antibioticus HA124 Against Phytophthora Blight Is Mediated by the Production of 4-Hydroxyphenylacetic Acid and Several Lytic Enzymes. - Curr Microbiol 59: 608-615.

[17] Lagerlof, J., Ayuke, F., Bejai, S., Jorge, G., Lagerqvist, E., Meijer, J., Muturi, J. J., Soderlund, S. (2015): Potential side effects of biocontrol and plant-growth promoting Bacillus amyloliquefaciens bacteria on earthworms. - Appl Soil Ecol 96: 159-164.

[18] McGrann, G. R. D., Gladders, P., Smith, J. A., Burnett, F. (2016): Control of clubroot (Plasmodiophora brassicae) in oilseed rape using varietal resistance and soil amendments. - Field Crops Research 186: 146-156.

[19] Nannipieri, P., Ceccanti, B., Cervelli, S., Sequi, P. (1974): Use of 0.1 m pyrophosphate to extract urease from a podzol. - Soil Biology and Biochemistry 6: 359-362.

[20] Niwa, R., Nomura, Y., Osaki, M., Ezawa, T. (2008): Suppression of clubroot disease under neutral $\mathrm{pH}$ caused by inhibition of spore germination of Plasmodiophora brassicae in the rhizosphere. - Plant Pathol 57: 445-452.

[21] Ruaro, L., Lima, V. D., Ribeiro, P. J. (2009): Influence of boron, nitrogen sources and soil $\mathrm{pH}$ on the control of club root of crucifers caused by Plasmodiophora brassicae. - Trop Plant Pathol 34: 231-238.

[22] Shakeel, Q., Lyu, A., Zhang, J., Wu, M., Chen, S., Chen, W., Li, G., Yang, L. (2016): Optimization of the cultural medium and conditions for production of antifungal substances by Streptomyces platensis 3-10 and evaluation of its efficacy in suppression of clubroot disease (Plasmodiophora brassicae) of oilseed rape. - Biological Control 101: 59-68.

[23] Shrestha, K., Stevens, S., Shrestha, P., Adetutu, E. M., Walsh, K. B., Ball, A. S., Midmore, D. J. (2015): Characterisation of the soil microbial community of cultivated and uncultivated vertisol in Australia under several management regimes. - Agr Ecosyst Environ 199: 418-427.

[24] Simmons, C. W., Higgins, B., Staley, S., Joh, L. D., Simmons, B. A., Singer, S. W., Stapleton, J. J., VanderGheynst, J. S. (2016): The role of organic matter amendment level on soil heating, organic acid accumulation, and development of bacterial communities in solarized soil. - Appl Soil Ecol 106: 37-46.

[25] Vance, E. D., Brookes, P. C., Jenkinson, D. S. (1987): An extraction method for measuring soil microbial biomass C. - Soil Biology and Biochemistry 19: 703-707.

[26] Wang, J., Zhu, B., Zhang, J., Müller, C., Cai, Z. (2015): Mechanisms of soil N dynamics following long-term application of organic fertilizers to subtropical rain-fed purple soil in China. - Soil Biology and Biochemistry 91: 222-231.

[27] Wang, L., Yang, F., Yaoyao, E., Yuan, J., Raza, W., Huang, Q. W., Shen, Q. R. (2016): Long-Term Application of Bioorganic Fertilizers Improved Soil Biochemical Properties and Microbial Communities of an Apple Orchard Soil. - Front Microbiol 7.

[28] Wang, M. Y., Wu, C. N., Cheng, Z. H., Meng, H. W., Zhang, M. R., Zhang, H. J. (2014): Soil Chemical Property Changes in Eggplant/Garlic Relay Intercropping Systems under Continuous Cropping. - Plos One 9.

[29] Wei, W., Li, Q. T., Chu, Y. N., Reiter, R. J., Yu, X. M., Zhu, D. H., Zhang, W. K., Ma, B. A., Lin, Q., Zhang, J. S., Chen, S. Y. (2015a): Melatonin enhances plant growth and abiotic stress tolerance in soybean plants. - J Exp Bot 66: 695-707. 
[30] Wei, W., Xu, Y. L., Li, S. X., Zhu, L., Song, J. (2015b): Developing suppressive soil for root diseases of soybean with continuous long-term cropping of soybean in black soil of Northeast China. - Acta Agr Scand B-S P 65: 279-285.

[31] Xiong, W., Zhao, Q. Y., Zhao, J., Xun, W. B., Li, R., Zhang, R. F., Wu, H. S., Shen, Q. R. (2015): Different Continuous Cropping Spans Significantly Affect Microbial Community Membership and Structure in a Vanilla-Grown Soil as Revealed by Deep Pyrosequencing. - Microb Ecol 70: 209-218.

[32] Yakushev, A. V., Kuznetsova, I. N., Blagodatskaya, E. V., Blagodatsky, S. A. (2014): Temperature Dependence of the Activity of Polyphenol Peroxidases and Polyphenol Oxidases in Modern and Buried Soils. - Eurasian Soil Sci+ 47: 459-465.

[33] Yin, C. T., Jones, K. L., Peterson, D. E., Garrett, K. A., Hulbert, S. H., Paulitz, T. C. (2010): Members of soil bacterial communities sensitive to tillage and crop rotation. Soil Biol Biochem 42: 2111-2118.

[34] Zhang, B., Gao, Q., Xu, S., Ma, L., Tian, C. (2016): Long-term effect of residue return and fertilization on microbial biomass and community composition of a clay loam soil. J Agr Sci-Cambridge 154: 1051-1061.

\section{APPENDIX}

\section{Correlation of soil enzyme activities and soil characteristics}

Table A1. Pearson correlations between URE, SUC, PPO, CAT activities and soil characteristics under different treatments for soil shallow layer samples $(0-20 \mathrm{~cm})$

\begin{tabular}{|c|c|c|c|c|c|c|c|}
\hline & & pH & Total N & Total P & Available N & Available P & Organic Matter \\
\hline URE & $\begin{array}{l}\text { Pearson Corr. } \\
\text { Sig. }\end{array}$ & $\begin{array}{c}0.816 \\
3.68 \mathrm{E}-5\end{array}$ & $\begin{array}{c}0.874 \\
2.15 \mathrm{E}-6\end{array}$ & $\begin{array}{l}0.111 \\
0.662\end{array}$ & $\begin{array}{l}0.569 \\
0.014\end{array}$ & $\begin{array}{l}-0.156 \\
0.538\end{array}$ & $\begin{array}{c}0.899 \\
3.92 \mathrm{E}-7\end{array}$ \\
\hline \multirow{2}{*}{ SUC } & \multirow{2}{*}{$\begin{array}{l}\text { Pearson Corr. } \\
\text { Sig. }\end{array}$} & 0.860 & 0.870 & 0.240 & 0.511 & -0.241 & 0.750 \\
\hline & & $4.79 \mathrm{E}-6$ & $2.65 \mathrm{E}-6$ & 0.339 & 0.030 & 0.336 & $3.47 \mathrm{E}-4$ \\
\hline \multirow{2}{*}{ PPO } & \multirow{2}{*}{$\begin{array}{c}\text { Pearson Corr. } \\
\text { Sig. }\end{array}$} & 0.786 & 0.808 & 0.102 & 0.618 & -0.155 & 0.8127 \\
\hline & & $1.10 \mathrm{E}-4$ & $4.90 \mathrm{E}-5$ & 0.688 & 0.006 & 0.540 & 4.267E-5 \\
\hline \multirow{2}{*}{ CAT } & Pearson Corr. & -0.864 & -0.887 & -0.238 & -0.659 & 0.096 & -0.825 \\
\hline & Sig. & $3.91 \mathrm{E}-6$ & $9.45 \mathrm{E}-7$ & 0.340 & 0.003 & 0.703 & $2.53 \mathrm{E}-5$ \\
\hline
\end{tabular}

2-tailed test significance is used

\section{Soil bacterial community structure and diversity}

Table A2. Sample statistics

\begin{tabular}{c|c|c|c}
\hline Sample & Sequences & Bases (bp) & Average Length (bp) \\
\hline CTS & 23680 & 9383057 & 396.24 \\
EMT & 20453 & 8102610 & 396.16 \\
NTS & 32315 & 12808208 & 396.35 \\
LIM & 23773 & 9422177 & 396.34 \\
LOT & 23616 & 9360053 & 396.34 \\
OFT & 25554 & 10131604 & 396.34 \\
\hline
\end{tabular}


Table A3. Percent content of all bacteria detected under the six treatments

\begin{tabular}{|c|c|c|c|c|c|c|}
\hline Taxon & CTS & EMT & LIM & LOF & NTS & OFT \\
\hline Subgroup_6_norank & 6.395 & 12.517 & 9.723 & 10.295 & 7.803 & 18.618 \\
\hline Nitrosomonadaceae_uncultured & 6.590 & 4.486 & 9.563 & 12.531 & 5.579 & 4.635 \\
\hline Lysobacter & 0.407 & 1.476 & 0.390 & 1.066 & 22.319 & 0.921 \\
\hline Xanthomonadales_norank & 3.221 & 2.179 & 4.437 & 4.520 & 4.427 & 1.765 \\
\hline RB41_norank & 1.628 & 0.831 & 3.096 & 1.711 & 2.823 & 2.859 \\
\hline Flexibacter & 2.029 & 1.400 & 3.886 & 2.824 & 1.561 & 1.638 \\
\hline Pseudoxanthomonas & 0.648 & 0.116 & 0.010 & 12.416 & 0.337 & 0.022 \\
\hline Lactococcus & 2.132 & 0.633 & 3.741 & 1.402 & 3.157 & 0.661 \\
\hline Steroidobacter & 2.149 & 0.819 & 2.191 & 2.446 & 2.744 & 0.594 \\
\hline 0319-6A21_norank & 1.095 & 2.226 & 1.846 & 2.200 & 1.899 & 1.371 \\
\hline Gemmatimonadaceae_uncultured & 1.966 & 1.761 & 1.591 & 1.018 & 1.622 & 2.748 \\
\hline Candidate_division_WA3_norank & 1.662 & 2.615 & 1.886 & 2.389 & 0.542 & 1.782 \\
\hline Anaerolineaceae_uncultured & 1.129 & 1.203 & 2.251 & 1.276 & 0.334 & 2.565 \\
\hline Gemmatimonas & 1.467 & 1.987 & 1.280 & 0.824 & 0.019 & 1.460 \\
\hline Haliangium & 1.192 & 0.569 & 2.201 & 1.197 & 0.485 & 0.672 \\
\hline WD2101_soil_group_norank & 1.112 & 1.284 & 0.955 & 0.887 & 0.640 & 1.532 \\
\hline Xanthomonadaceae_unclassified & 0.923 & 3.213 & 0.350 & 0.919 & 0.315 & 0.544 \\
\hline OM190_norank & 0.762 & 0.575 & 1.461 & 0.866 & 0.997 & 0.855 \\
\hline Rhodospirillaceae_uncultured & 0.699 & 0.378 & 0.730 & 0.614 & 2.194 & 0.389 \\
\hline Acidobacteriaceae_Subgroup_1_uncultured & 2.556 & 0.506 & 1.541 & 0.987 & 0.027 & 0.278 \\
\hline GR-WP33-30_norank & 0.756 & 0.552 & 0.965 & 0.619 & 1.114 & 1.205 \\
\hline Aquicella & 0.946 & 2.167 & 0.560 & 0.882 & 0.322 & 0.694 \\
\hline Comamonadaceae_unclassified & 0.395 & 1.185 & 0.490 & 0.362 & 1.876 & 0.350 \\
\hline TRA3-20_norank & 0.630 & 0.471 & 1.706 & 1.155 & 0.478 & 0.572 \\
\hline Myxococcales_norank & 1.054 & 0.581 & 1.425 & 0.945 & 0.584 & 0.339 \\
\hline Bacillus & 0.321 & 1.650 & 0.375 & 0.199 & 0.186 & 2.559 \\
\hline Subgroup_7_norank & 0.350 & 0.947 & 0.720 & 0.961 & 0.345 & 1.732 \\
\hline Planctomycetaceae_uncultured & 0.470 & 1.075 & 0.945 & 0.509 & 0.963 & 0.788 \\
\hline Nitrospira & 0.854 & 0.378 & 1.676 & 0.751 & 0.299 & 0.766 \\
\hline Gaiella & 0.848 & 1.540 & 0.630 & 0.215 & 0.504 & 0.999 \\
\hline SC-I-84_norank & 0.739 & 1.127 & 0.560 & 0.772 & 0.307 & 1.143 \\
\hline KCM-B-112_norank & 0.000 & 0.012 & 0.005 & 0.000 & 2.797 & 0.000 \\
\hline Subgroup_25_norank & 0.132 & 1.017 & 0.510 & 0.724 & 0.572 & 0.805 \\
\hline Arenimonas & 1.060 & 1.005 & 0.480 & 0.378 & 0.277 & 0.727 \\
\hline Chitinophagaceae_uncultured & 0.648 & 1.517 & 0.415 & 0.541 & 0.011 & 0.927 \\
\hline Sorangium & 3.444 & 0.017 & 0.325 & 0.189 & 0.030 & 0.061 \\
\hline Sphingomonas & 0.946 & 0.110 & 0.035 & 2.730 & 0.004 & 0.061 \\
\hline Gaiellales_norank & 0.848 & 1.290 & 0.550 & 0.142 & 0.273 & 0.705 \\
\hline Rhizobium & 2.160 & 0.064 & 0.040 & 0.262 & 0.917 & 0.044 \\
\hline Piscinibacter & 0.390 & 1.644 & 0.215 & 0.304 & 0.440 & 0.505 \\
\hline Xanthobacteraceae_uncultured & 0.344 & 0.314 & 0.465 & 0.268 & 1.042 & 0.661 \\
\hline Solimonadaceae_uncultured & 0.080 & 0.442 & 0.140 & 0.278 & 0.068 & 1.898 \\
\hline Xanthomonas & 2.923 & 0.017 & 0.000 & 0.037 & 0.000 & 0.006 \\
\hline Sporocytophaga & 0.052 & 0.000 & 0.030 & 0.000 & 1.899 & 0.006 \\
\hline Oxalobacteraceae_unclassified & 0.659 & 0.395 & 0.015 & 1.228 & 0.011 & 0.505 \\
\hline Lineage_IIb_norank & 1.192 & 0.192 & 0.680 & 0.367 & 0.011 & 0.344 \\
\hline Gammaproteobacteria_unclassified & 0.453 & 1.029 & 0.055 & 0.247 & 0.368 & 0.488 \\
\hline Flavobacterium & 1.186 & 1.005 & 0.065 & 0.068 & 0.152 & 0.194 \\
\hline Massilia & 0.241 & 1.011 & 0.045 & 0.026 & 0.004 & 0.427 \\
\hline Others & 36.121 & 36.559 & 32.746 & 22.467 & 24.326 & 34.582 \\
\hline
\end{tabular}




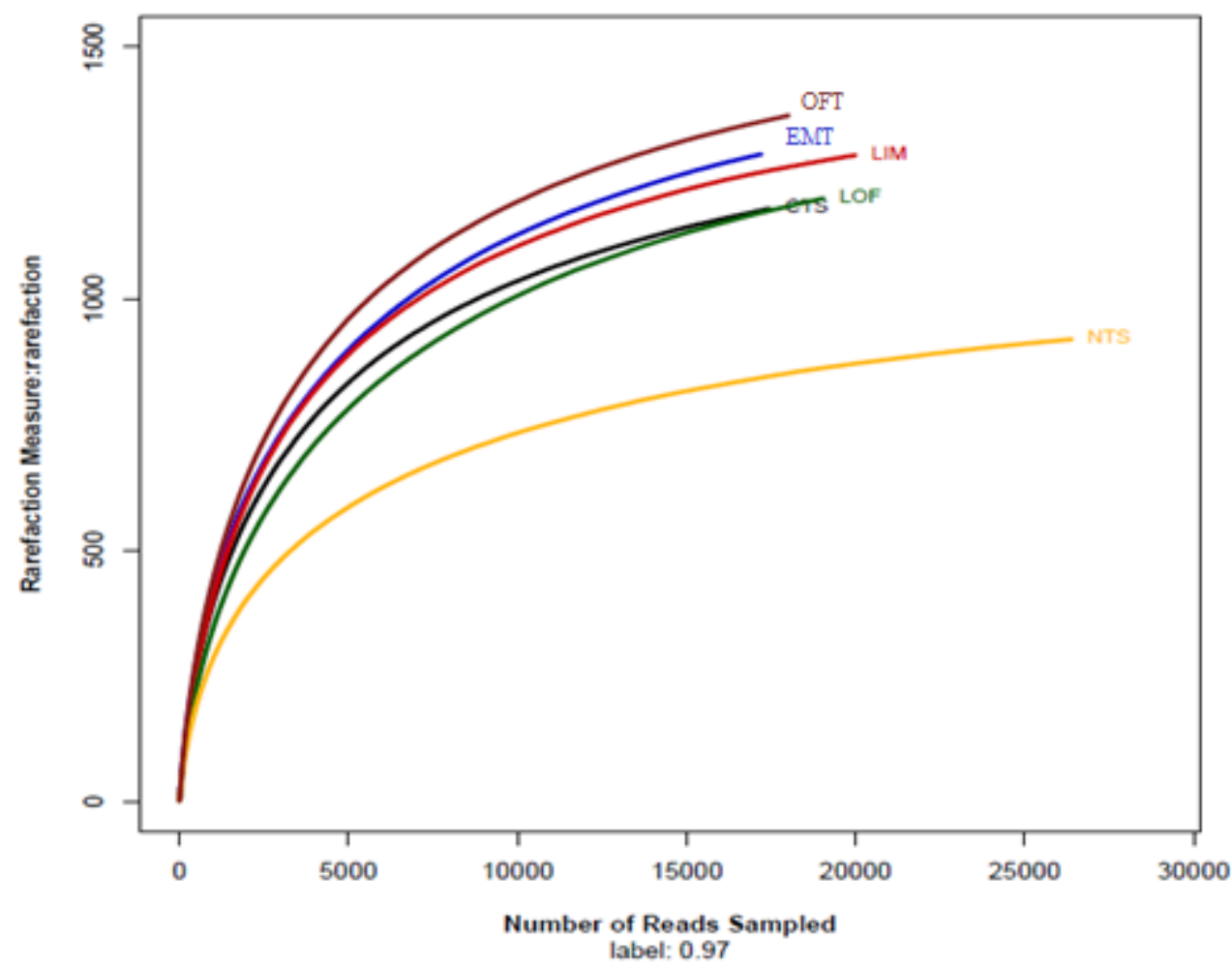

Figure A1. Rarefaction on species-abundance data. Using $97 \%$ similarity OTUs and mothur to analyze rarefaction. This graph was made by $R$ language tool

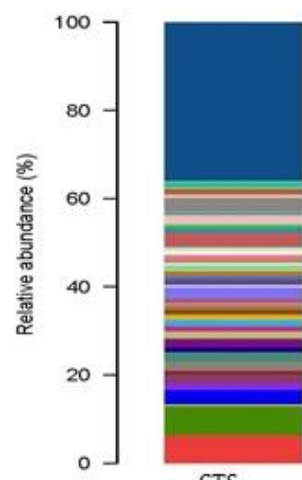

CTS

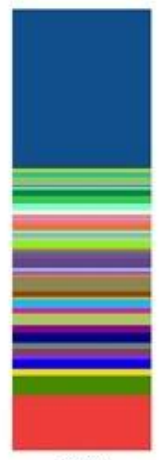

EMT

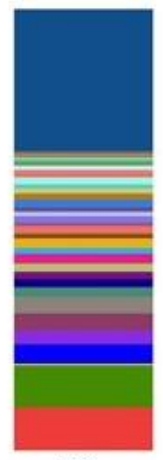

LIM

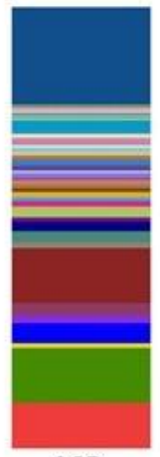

LOF

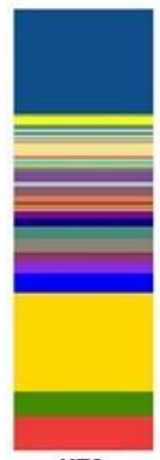

NTS

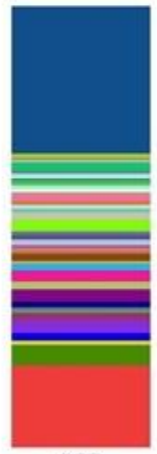

OFT
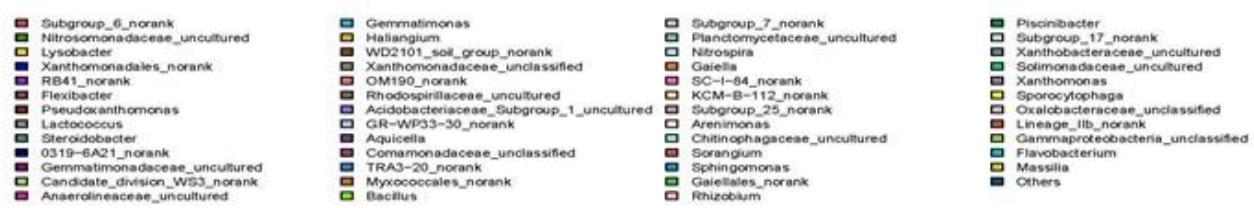

Figure A2. The relative abundance of different bacteria communities at the genus level in the soil samples from six treatments. The different bacteria genera are distinguished with different colors. Bacteria were defined as No Rank or unclassified if there was no match in the taxonomic database, the taxonomic information was under the threshold of reliability, or there was no taxonomic information 


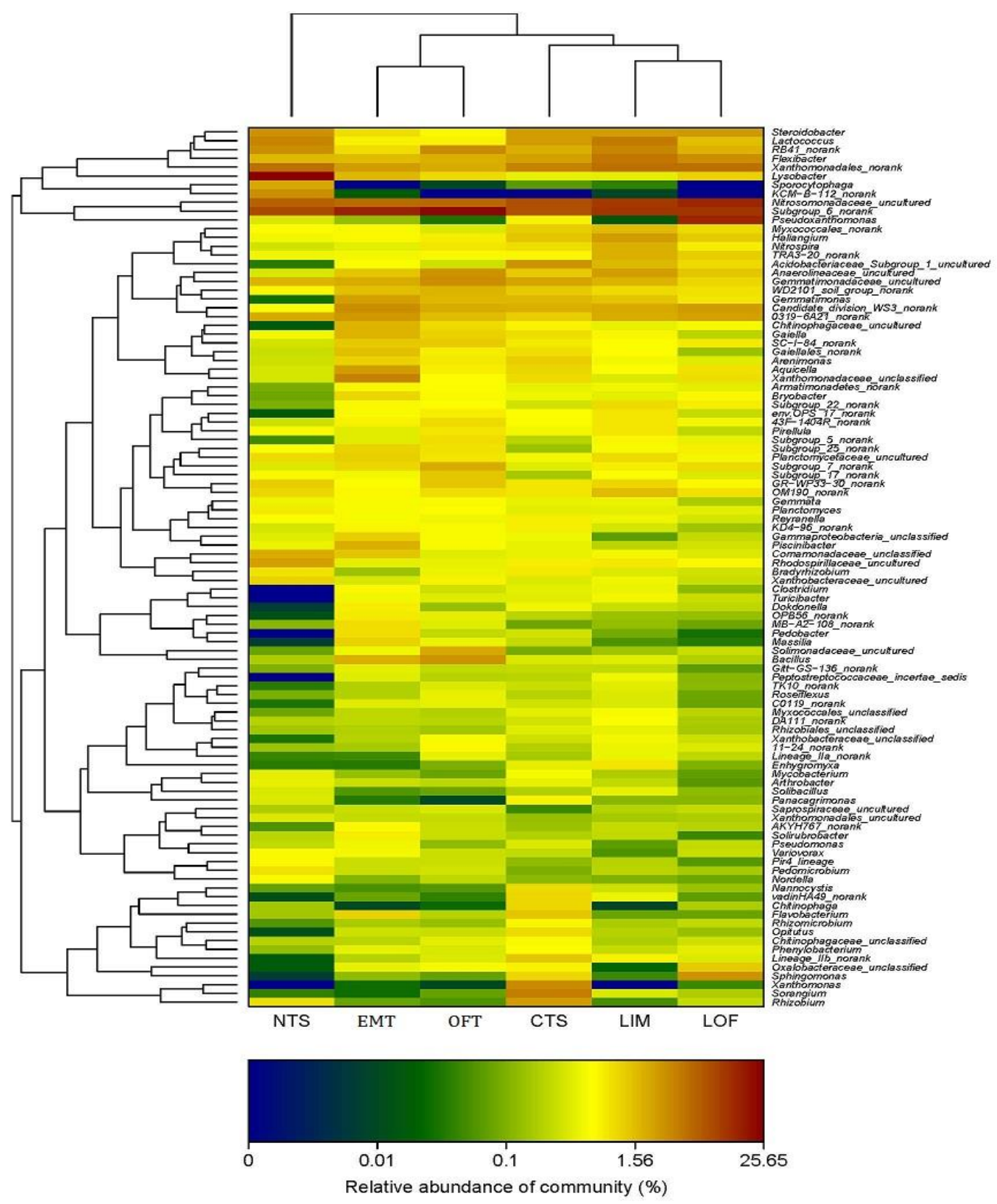

Figure A3. Double hierarchical dendrogram of the distribution on the 100 most abundant bacteria genera among the six treatment soils. The phylogenetic tree was calculated using the Neighbor-Joining method, and relationships among the treatments were determined using Bray distance and the complete clustering method. The heatmap plot depicts the relative percentage of each bacteria genus (variables clustering on the Y-axis) with in each treatment (X-axis clustering). The relative values for bacteria genera are depicted by color intensity with the legend indicated at the bottom of the figure. Clusters based on the distance of the six samples along the $X$-axis and the bacteria genus along the $Y$-axis are indicated at the top and left of the figure, respectively 


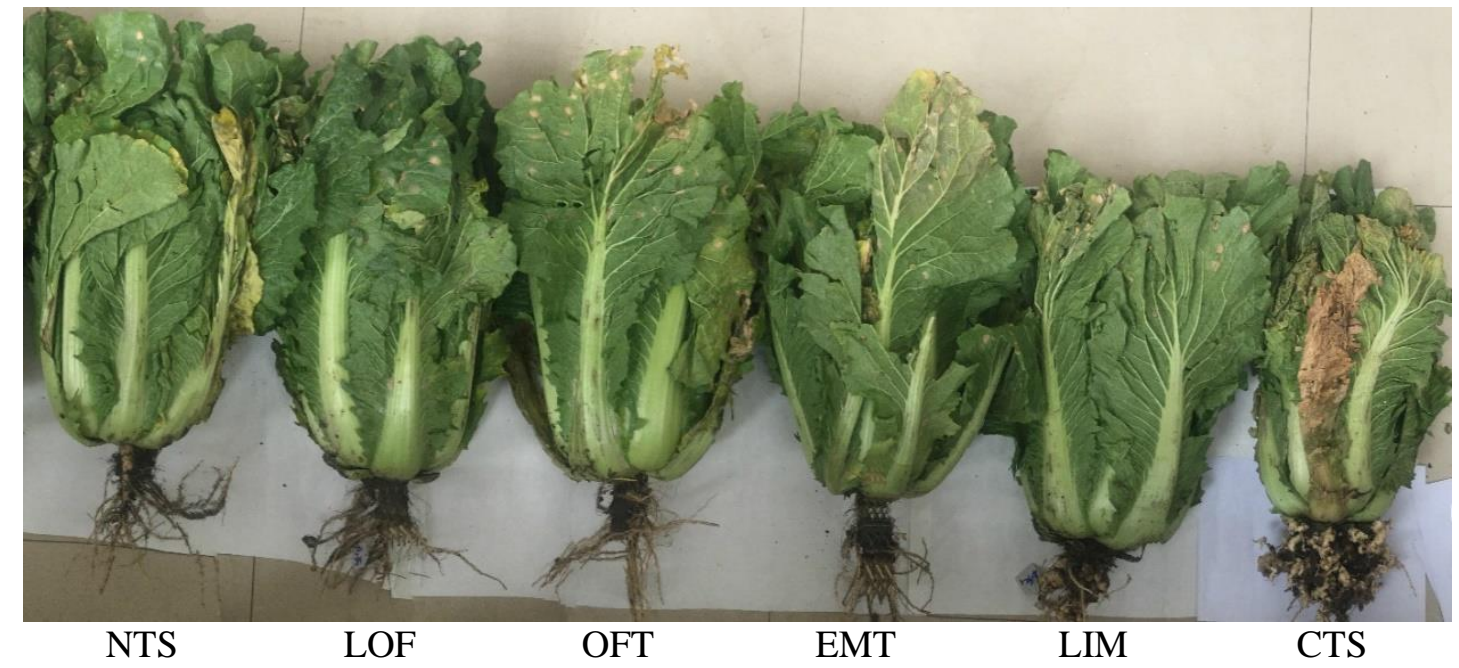

Figure A4. Photo of the experiment 